\title{
Success Rate of Trabeculectomy in Secondary Glaucoma after Vitrectomy in Kariadi Hospital, Semarang, Central Java
}

\author{
Farah Maulida $^{1}$, Fifin L.Rahmi ${ }^{2}$, Maharani Cahyono ${ }^{2}$ \\ ${ }^{1}$ Resident of Ophthalmology Department of Diponegoro University, Kariadi Hospital, Semarang, Central Java \\ ${ }^{2}$ Staff of Glaucoma, Opthalmology Department of Diponegoro University, Kariadi Hospital, Semarang, Central \\ Jawa \\ E-mail:drmaharani@gmail.com
}

\begin{abstract}
Objectives: Vitrectomy with intravitreal injections of gas or silicone oil is commonly used to treat vitreoretinal diseases such as rhegmatogenous retinal detachment, tractional retinal detachment, and vitreous hemorrhage. Some of these procedure can lead to short-term elevations in intraocular pressure (IOP) and ultimately long-term glaucomatous damage if not treated in a timely manner. Trabeculectomy is a widely performed filtering surgery used in these cases. This study is aimed to define the success rate of trabeculectomy for surgical treatment of secondary glaucoma after vitrectomy in Kariadi Hospital, Semarang, Central Java. Methods: Retrospective study was conducted in secondary glaucoma after vitrectomy patient who underwent trabeculectomy from November 2014-Januari 2019 in Kariadi Hospital. The secondary data of baseline IOP, 1 week, 2 weeks, 1 month, and 3 months after trabeculectomy is obtained from medical records.

Results: 19 eyes from 19 patients had mean preoperative IOP 35,56 $\pm 8,40 \mathrm{mmHg}, 1$ week $21,01 \pm 13,83 \mathrm{mmHg}, 2$ weeks $26,09 \pm 11,27 \mathrm{mmHg}, 1$ month $29,97 \pm 13,45 \mathrm{mmHg}$, and 3 months $25,47 \pm 13,43 \mathrm{mmHg}$. There was significant differences of IOP level in 1 week, 2 weeks, 3 months ( $\mathrm{p}<0.05)$, and not significant in 1 month ( $\mathrm{p} 0,171)$. Complete success rate of trabeculectomy in 1 month was $10,5 \%$ and 3 months $10,5 \%$. Qualified success rate in 1 month was $15,8 \%$ and 3 months $42,1 \%$. Failed in 1 month was $73,7 \%$ and 3 month $47,4 \%$.
\end{abstract}

Conclusions: Trabeculectomy in secondary glaucoma after vitrectomy has low success rate.

Keywords: Secondary Glaucoma, Trabeculectomy, Vitrectomy, IOP.

\begin{abstract}
ABSTRAK
Tujuan: Vitrektomi dengan tamponade gas atau silicone oil umumnya digunakan untuk menangani kelainan vitreoretina seperti rhegmatogenous retinal detachment, tractional retinal detachment, dan perdarahan vitreous. Beberapa prosedur ini dapat menyebabkan peningkatan tekanan intraokular (TIO) dalam jangka pendek dan dalam jangka panjang akhirnya terjadi glaukoma jika tidak diobati dengan tepat. Trabekulektomi adalah tindakan operatif yang digunakan dalam kasus ini. Penelitian ini bertujuan untuk mengidentifikasi tingkat
\end{abstract}


keberhasilan trabekulektomi pada glaukoma sekunder pasca vitrektomi di RSUP Kariadi, Semarang, Jawa Tengah.

Metode: Penelitian ini merupakan penelitian retrospektif pada pasien glaukoma sekunder pasca vitrektomi yang dilakukan trabekulektomi selama November 2014 sampai Januari 2019 di RSUP dr.Kariadi. Data sekunder TIO pre operasi, 1 minggu pasca operasi, 2 minggu pasca operasi, 1 bulan pasca operasi, dan 3 bulan pasca operasi diperoleh dari catatan medis pasien.

Hasil: 19 mata dari 19 pasien memiliki rata-rata TIO pre operasi 35,56 $\pm 8,40 \mathrm{mmHg}, 1 \mathrm{minggu}$ $21.01 \pm 13.83 \mathrm{mmHg}, 2$ minggu $26.09 \pm 11.27 \mathrm{mmHg}$, 1 bulan $29.97 \pm 13.45 \mathrm{mmHg}$, dan 3 bulan $25.47 \pm 13.43 \mathrm{mmHg}$. Terdapat perbedaan TIO yang signifikan pada 1 minggu, 2 minggu, 3 bulan ( $\mathrm{p}<0,05)$, dan tidak signifikan pada 1 bulan ( $\mathrm{p} 0.171)$. Complete success pada 1 bulan adalah 10,5\% dan 3 bulan 10,5\%. Qualified success 1 bulan adalah 15,8\% dan 3 bulan 42,1\%. Gagal pada 1 bulan adalah $73,7 \%$ dan 3 bulan $47,4 \%$.

Kesimpulan: Trabekulektomi pada glaukoma sekunder pasca vitrektomi dengan tamponade memiliki keberhasilan yang rendah.

Kata kunci: Glaukoma sekunder, trabekulektomi, vitrektomi, tekanan intraokular.

\section{INTRODUCTION}

$\mathrm{V}$ itrectomy is commonly used to treat vitreoretinal disease such as rhegmatogenous retinal detachment, tractional retinal detachment, and vitreous hemorrhage. Tampon used is silicone oil (SO) and gas. One of the complications of vitrectomy is an increase in intraocular pressure (IOP) caused by a variety of different mechanisms. ${ }^{1}$ Glaucoma after vitreoretinal surgery requires special attention to its etiology, pathophysiology, diagnosis, treatment, and prevention. It is important to distinguish between early (first week) and late (second week and later). In the early postoperative period, an increase in IOP occurs due to the viscoelastics, expanding gas bubble, pupillary block, inflammation, hemorrhage, choroidal edema, SO, or steroid response. ${ }^{1,2}$ Late onset is the result of neovascularization in the angle or emulsification of SO. ${ }^{1}$

Although patients in whom elevated IOP after vitrectomy and SO / gas tamponade can be controlled medically, many cases require surgical intervention. ${ }^{3}$ IOP elevation caused by $\mathrm{SO}$ is often resistant to drug therapy and has been shown to require surgical intervention such as SO evacuation or glaucoma surgery in about $40 \%$ of the eyes. ${ }^{4,5}$ Trabeculectomy in the eyes undergoing vitrectomy surgery and filled with SO tamponade may have a poor prognosis. Factors considered to cause poorer control include the presence of emulsified of SO and diabetes mellitus. ${ }^{4}$ This study was conducted to see the success rate of IOP reduction in secondary glaucoma patients after vitrectomy with trabeculectomy.

\section{METHODS}

\section{Study Design}

This was a retrospective study using secondary data taken from patient's medical records. The sample in this study was patients who suffered secondary glaucoma after vitrectomy surgery and underwent trabeculectomy during November 2014 to January 2019 in eye clinic at Kariadi Hospital. A sample of 19 patients whose names and medical record numbers were recorded. Then traced to get the data needed including age, sex, type of tamponade, baseline IOP, 1 week, 2 weeks, 1 month, and 3 months after trabeculectomy. The success rate of trabeculectomy surgery was divided into 3 groups. Complete success if IOP was <21 $\mathrm{mmHg}$ without medication. Qualified 
success if IOP was $<21 \mathrm{mmHg}$ with medication. Failed if IOP was $>21 \mathrm{mmHg}$ with medication. Then the data was analyzed into a computerized system.

\section{RESULTS}

There were 19 patients of secondary glaucoma after vitrectomy who underwent trabeculectomy sugery during November 2014 to January 2019. The patient's age range was 16 to 64 years with an average of $45.74 \pm 17.49$ years. Fifty seven point nine percent of the samples were male (table 1). Most of them used SO tampons (84.1\%).

Table 1. Characteristics of the Patients

\begin{tabular}{|l|c|c|c|c|}
\hline \multicolumn{1}{|c|}{ Variable } & F & $\%$ & Mean \pm SD & Median \\
\hline Sex & & & & \\
\hline Male & 11 & 57,9 & & \\
\hline Female & 8 & 42,1 & & \\
\hline Age (yo) & & & $45,74 \pm 17,49$ & $55(16-64)$ \\
\hline Tampon & & & & \\
\hline Gas & 3 & 15,8 & & \\
\hline SO & 16 & 84,1 & & \\
\hline
\end{tabular}

The baseline IOP examination showed an average of $35.56 \pm 8.40 \mathrm{mmHg}$. The lowest IOP was obtained at 1 week postoperatively which was $21.01 \pm 13.83$ mmHg (table 2).

Table 2. Baseline and after vitrectomy IOP values

\begin{tabular}{|c|c|c|}
\hline IOP & $\begin{array}{c}\text { Mean } \pm \text { SD } \\
(\mathbf{m m H g})\end{array}$ & Median $(\boldsymbol{m i n}-\mathbf{m a x})$ \\
\hline Baseline & $35,56 \pm 8,40$ & $31,8(25,8-50,6)$ \\
\hline 1 week & $21,01 \pm 13,83$ & $18,5(5,8-54,9)$ \\
\hline $\mathbf{2}$ weeks & $26,09 \pm 11,27$ & $26(0,9-45,3)$ \\
\hline $\mathbf{1}$ mont & $29,97 \pm 13,45$ & $29,3(6,2-52,2)$ \\
\hline 3 months & $25,47 \pm 13,43$ & $21(10,2-58,7)$ \\
\hline
\end{tabular}

All From the data obtained after analysis of paired $t$ test, significant differences $(p<0.05)$ were found at 1 week, 2 weeks, and 3 months postoperatively. Not significant difference $(p>0.05)$ was found at 1 month postoperatively (table 3 ).
Table 3. The results of paired t test of IOP

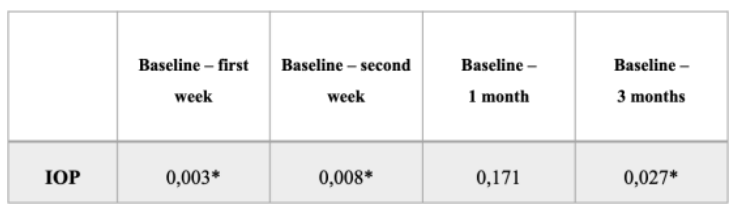

Explanation: * Significant $(p<0,05)$; Wilcoxon

Complete success rate of trabeculectomy (table 4) in 1 month postoperatively was $2(10,5 \%)$, qualified success was $3(15,8 \%)$, failed was 14 $(73,7 \%)$. In 3 months postoperatively complete success rate was $2(10,5 \%)$, qualified success was $8(42,1 \%)$, and failed was $9(47,4 \%)$.

Table 4. Classification of the success of trabeculectomy

\begin{tabular}{|l|c|c|}
\hline \multicolumn{1}{|c|}{ Variable } & F & \% \\
\hline 1 month postoperatively & & \\
\hline Complete success & & \\
\hline Qualified success & 2 & 10,5 \\
\hline Failed & 3 & 15,8 \\
\hline 3 months postoperatively & 14 & 73,7 \\
\hline Complete success & & \\
\hline Qualified success & & \\
\hline Failed & 2 & 10,5 \\
\hline
\end{tabular}

\section{DISCUSSION}

Vitrectomy with SO tamponade in retinal detachment and vitreous hemorrhage were the most common causes of secondary glaucoma after vitrectomy. The incidence of increase postoperative IOP varies. Secondary glaucoma occurs due to reduced trabecular flow from aqueous humor. Increased IOP occurs because of the migration of SO into anterior chamber and obstruction of the trabecular meshwork (early post-op IOP increase) usually due to overfill of SO. SO particles in the anterior chamber are partially phagocyted by macrophages and accumulate in the trabecular meshwork especially in the upper quadrant and can induce trabeculitis (intermediate and late onset IOP increase). Prolonged contact of 
SO with the trabecular meshwork may cause permanent structural changes. Risk factors for developing IOP elevation following vitrectomy with SO include preexisting ocular hypertension or glaucoma, diabetes mellitus, and aphakia. ${ }^{6}$

Topical and systemic antiglaucoma drugs can effectively control IOP in a majority of patients, and topical steroids are given after surgery to control inflammation. $^{7}$ Although most patients who developed secondary glaucoma can be managed medically, some require surgical intervention. Evacuation of SO with or without concurrent glaucoma surgery has been performed to lower IOP, but evacuation carries some risk of retinal detachment. The benefits of evacuating SO in patients with elevated IOP are still controversial. $^{8}$ Jonas et al. ${ }^{9}$ found that $93.4 \%$ (185 of 198) of patients with a secondary increase in IOP after SO tamponade had normalization of IOP after SO evacuation, and concluded that SO evacuation was the preferred glaucoma surgery to reduce IOP. However, Flaxel $e t$ $a l .{ }^{10}$ reported that elevated IOP persisted in all eyes (62 eyes) after SO evacuation. Furthermore, SO evacuation itself can cause IOP elevation by splitting SO droplets into smaller bubbles, which are more likely to obstruct the trabecular meshwork.

The surgical management of patients with SO glaucoma should be modified according to the individual clinical presentation. Patients with complete synechial angle closure would not be expected to have normalization of IOP with SO evacuation alone. Glaucoma surgery would seem to be indicated in such cases, and the decision as to whether to concomitantly SO evacuation depends on an assessment of relative risk of redetachment. When emulsified or nonemulsified SO blocks the trabecular meshwork directly, it is reasonable to proceed with SO evacuation alone if the retina is completely attached with closure of all tears and release of all areas of traction. However, patients must be educated about the possibility of the need for subsequent glaucoma surgery. ${ }^{8}$

The success rate of trabeculectomy in this study was only $10.5 \%$. Low success rate was resulted from severe inflammation induced by SO droplets in the trabecular meshwork, scleral ostium, and subconjunctival space after surgery. Inflammation induced severe fibrosis and histopathology showed granulomatous foreign body reactions. The upward migration of SO and conjunctival scarring occured after vitrectomy. Because the success rate of trabeculectomy depends mainly on survival blebs. Conjunctival scarring after ocular surgery was a major factor in failure of trabeculectomy. Glaucoma Drainage Device (GDD) offers a good surgical option in cases of refractory glaucoma associated with $\mathrm{SO}$, but there is also a possibility of SO escape via the drainage tube. ${ }^{11}$ If $\mathrm{SO}$ remains in the eye, the GDD should be positioned in one of the inferior quadrants. With the tube located inferiorly, any migration of SO into the anterior chamber is less likely to drain through the tube into the subconjunctival space, which can trigger an inflammatory reaction. ${ }^{12}$

Three samples were obtained using gas tamponade in this study. Complete success rate was $33.3 \%$ at 1 month and 3 months postoperatively. Gas tamponade for repair retinal detachment can be associated with a significant IOP spike during the rapid phase of gas expansion. Sulfur hexafluoride $\left(\mathrm{SF}_{6}\right)$ and perfluoropropane $\left(\mathrm{C}_{3} \mathrm{~F}_{8}\right)$ achieve retinal tamponade by expanding within the vitreous cavity. Elevated IOP is directly related to the expansile property and final volume of the intravitreal gas bubble. $\mathrm{C}_{3} \mathrm{~F}_{8}$ and $\mathrm{SF}_{6}$ commonly used high molecular weight gases in nonexpansile concentrations of $14 \%$ and $18 \%$, respectively. ${ }^{7}$ Pure $\mathrm{SF}_{6}$ expands to $2-2.5$ times its original volume within 24-36 hours, and pure $\mathrm{C}_{3} \mathrm{~F}_{8}$ expands to 3-4 times its original volume within the first 3 days. 
The maximum expansion of these two gases occurs within the first 6 hours. When gas gets diluted to a $40 \%$ concentration, further expansion occurs slowly and balanced by the vitreous loss. The nonexpansile concentration for SF6 is $18 \%$ and for $\mathrm{C} 3 \mathrm{~F} 8$ is $14 \%{ }^{1}$ Because of this concentration, an increase in IOP in the initial postoperative period is common. These gases can remain in the eye for 10-14 days for $\mathrm{SF}_{6}$ and up to 55-65 days for $\mathrm{C}_{3} \mathrm{~F}_{8}{ }^{7}$ Secondary glaucoma develops by both open and closed angle mechanisms. Angle closure can occur with or without pupillary block. Angle closure with pupillary block occurs when the anterior displacement of the lens-iris diaphragm results in iris bombe and iridocorneal touch. This mechanism can despite the patient assuming a prone position. There are also cases of closedangle glaucoma with the enlarging gas bubble causing iridocorneal apposition without pupillary block. In addition, openangle glaucoma occurs when the rate of expansion of the gas exceeds the rate of egress of the aqueous humor through the trabecular meshwork. Changes in atmospheric pressure can result in expansion of intraocular gas volume and result in an acute increase of IOP. ${ }^{7}$

Risk factors for increased IOP after intravitreal gas tamponade include the concentration of gas used, older patients, posoperative fibrin in the anterior chamber, concurrent use of scleral buckle, and intraoperative endophotocoagulation. ${ }^{7}$ All patients undergoing gas injection should maintain a facedown position following surgery in order to augment the tamponade effect of gas bubbles as well as to decrease anterior displacement of the lens-iris diaphragm. ${ }^{7}$

IOP elevations in the initial postoperative period with gas tampons should be treated with topical and systemic antiglaucoma agents. The treatment of high elevation IOP is based on the underlying causative mechanism. If pupillary block is present, an inferior laser peripheral iridotomy is necessary. The attachment of iridocornea must be treated immediately to prevent peripheral anterior synechiae to prevent an increase in IOP. This can be achieved by partial removal of the intravitreal gas and reformation the anterior chamber with viscoelastic. In addition, paracentesis can immediately lower pressures in the setting where topical medication ineffective. ${ }^{7}$ The conjunctiva may be in poor condition with scarring from a previous vitrectomy. GDD is an option when there is a high risk of failure with trabeculectomy surgery. ${ }^{8}$

\section{LIMITATIONS}

This study requires a larger number of samples. In this study there were only 19 patients, although the sample used was a total sample. Further research is needed to determine the factors that cause low success rate of trabeculectomy in secondary glaucoma after vitrectomy.

\section{CONCLUSION}

Trabeculectomy in secondary glaucoma after vitrectomy has low success rate. However, almost half of the IOPs in 3 months after trabeculectomy can be controlled with drugs.

\section{REFERENCES}

1. Fingeret, M. and Dickerson, J. (2018). The Kahook M, Schuman J. Chandler and Grant's Glaucoma. 5th ed. Thorofare: SLACK Incorporated; 2013:327-334.

2. Chang S. LXII Edward Jackson lecture: open angle glaucoma after vitrectomy. Am J Ophthalmol. 2006;141(6):1033-1043.

3. Al-Jazzaf A, Netland P, Charles S. Incidence and Management of Elevated Intraocular Pressure After Silicone Oil Injection. Journal of Glaucoma. 2005;14(1):40-46.

4. Singh D, Chandra A, Sihota R, Kumar S, Gupta V. Long-Term Success Of MitomycinAugmented Trabeculectomy For Glaucoma After Vitreoretinal Surgery With Silicone Oil Insertion. Retina. 2014;34(1):123-128.

5. Honavar SG, Goyal M, Majji AB, et al. Glaucoma after pars plana vitrectomy and silicone oil injection for complicated retinal detachments. Ophthalmology 1999;106:169176. 
6. Terminology and guidelines for glaucoma. 4th ed. Savona Italy: SvetPrint; 2014.

7. Samples J, Schacknow P. Clinical Glaucoma Care. New York, NY: Springer New York; 2014:645-649.

8. Kornmann H, Gedde S. Glaucoma management after vitreoretinal surgeries. Current Opinion in Ophthalmology. 2016;27(2):125-131.

9. Jonas JB, Knorr HL, Rank RM, et al. Intraocular pressure and silicone oil endotamponade. J Glaucoma. 2001; 10:102108. [PubMed: 11316091].

10. Flaxel CJ, Mitchell SM, Aylward GW. Visual outcome after silicone oil removal and recurrent retinal detachment repair. Eye (Lond). 2000; 14:834-838. [PubMed: 11584838].

11. Senn P, Buchi ER, Daicker B, et al. Bubbles in the bleb: troubles in the bleb? Molteno implant and intraocular tamponade with silicone oil in an aphakic patient. Ophthalmic Surg. 1994; 25:379-382. [PubMed: 8090417].

12. Hyung SM, Min JP. Subconjunctival silicone oil drainage through the Molteno implant. Korean J Ophthalmol. 1998; 12:73-75. [PubMed: 9753954]. 